\title{
KONSEP FITRAH MANUSIA DAN IMPLIKASINYA DALAM PENDIDIKAN ISLAM
}

\author{
Mualimin \\ mualimin@gmail.com \\ Universitas Negeri Lampung
}

\begin{abstract}
Human existence begins with a weakness and disability that will then move towards strength. Humans can easily utilize the grace and gift that is bestowed upon him, but man must fulfill a duty to his God. Human dignity with his Lord is not measured by how high his skill and position, his or her wealth, and his wealth. But when God measured it is his taqwa. Human beings in the Islamic perspective will remain born in a state of fithrah, that is pure, clean, free from all sin, and has the tendency to accept religion, faith, and faith. Humans become good or bad are the result of educational and environmental factors, not their original habits. According to Abd al-Rahman al-Bani quoted by an-Nahlawi states the task of Islamic education is to maintain and maintain the students' nature, then develop and prepare for all the potential possessed, by directing the nature and potential of existing and towards goodness and perfection, and realizing a program gradually. (Nahlawi, 1996) The development of human nature can be done with various learning activities. That is through an institution. The development of human nature can be done by learning activities. That is through various institutions. Learning that is not focused is through education only in school, but also can be done outside the school, whether in the family, in the community, or through the existing social science constitution.
\end{abstract}

Keywords: Human Fitrah and Islamic Education

\begin{abstract}
Abstrak
Keberadaan manusia dimulai dari sebuah kelemahan dan ketidak mampuan yang kemudian akan bergerak ke arah kekuatan. Manusia dapat dengan mudah memanfaatkan rahmat dan karunia yang dilimpahkan kepada dirinya, namun manusia harus menunaikan suatu kewajiban kepada Tuhannya. Martabat manusia disisi Tuhannya tidaklah diukur dari seberapa tinggi pengkat dan jabatannya, nasabnya, maupun kekayaannya. Namun disaat Allah yang diukur adalah ketaqwaannya. Manusia dalam perspektif Islam akan tetap dilahirkan dalam keadaan fithrah, yaitu suci, bersih, bebas dari segala dosa, dan memiliki kecenderungan sikap menerima agama, iman, dan tauhid. Manusia menjadi baik atau buruknya adalah akibat faktor pendidikan dan lingkungan, bukan kepada tabiat aslinya.Menurut Abd al-Rahman al-Bani yang dikutip an-Nahlawi menyatakan tugas pendidikan islam adalah menjaga dan memelihara fitrah peserta didik, kemudian mengembangkan dan mempersiapkan ssemua potensi yang dimiliki, dengan mengarahkan fitrah dan potensi yang ada dan menuju kebaikan dan kesempurnaan, serta merealisasikan suatu program tersebut secara lebih bertahap. (Nahlawi, 1996) Pengembangan fitrah manusia dapat dilakukan dengan berbagai kegiatan belajar. Yaitu melalui sebuah institusi. Pengembangan fitrah manusia dapat dilakukan dengan kegiatan belajar. Yaitu melalui berbagai institusi. Belajar yang dimaksud dengan tidak terfokus yakni melalui pendidikan disekolah saja, tetapi juga dapat dilakukan diluar sekolah, baik dalam keluarga, masyarakat, maupun lewat isnstitusi sosial keagamaan yang ada.
\end{abstract}

Kata Kunci: Fitrah Manusia dan Pendidikan Islam 


\section{PENDAHULUAN}

Manusia merupakan makhluk yang sangat istimewa. karena manusia dikaruniai akal sebagai keistimewaannya dibandingkan dengan dengan makhluk-makhluk yang lain. Manusia merupakan makhluk yang mulia dari semua makhluk yang ada di alam bumi ini. Allah yang memberikan manusia dengan berbagai keutamaan dengan ciri khas yang membedakan makhluk satu dengan makhluk yang lainnya.

Dalam pandangan Islam menyatakan bahwa kemampuan dasar dan keunggulan manusia dapat dibandingkan dengan makhluk lainnya yang disebut dengan fitrah, kata “ Fitrah" yang dalam pengertian etimologi mengandung arti kejadian. Secara umum makna fitrah dalam Al-Qur'an dapat dikelompokan kedalam empat makna

1. Sebagai proses penciptaan langit dan bumi

2. Proses penciptaan untuk manusia

3. Mengatur alam semesta dan isinya secara lebih serasi dan seimbang

4. Memberikan makna pada agama Allah sebagai acuan dasar dan pedoma bagi manusia dalam menjalankan setiap tugas dan fungsinya.(S, 2001)

Allah SWT tidaklah menciptakan manusia melainkan hanyalah untuk beribadah serta menyembah kepada Allah semata. Selain manusia diciptakan Allah menjadi hamba-Nya, dan menjadi penguasa (khalifah) di muka bumi. Allah SWT telah menetapkan bahwasannya manusia adalah makhluk yang Allah ciptakan paling sempurna. Atas kesempurnaan inilah Allah SWT ketika pertama kali menciptakan Nabi Adam sebagai manusia pertama, Allah pun memerintahkan kepada para malaikat untuk bersujud kepada Nabi Adam. Para malaikat pun akhirnya bersujud kepada Adam kecuali iblis yang tidak mau sujud kepada Adam.

Keberadaan manusia dimulai dari kelemahannya dan ketidakmampuan yang kemudian bergerak menjadi arah kekuatan. Manusia dapat dengan leluasa memanfaatkan rahmat dan karunia yang dilimpahkan Allah SWT kepada dirinya, namun manusia harus terus menunaikan kewajiban kepada Tuhannya. Martabat manusia disisi Tuhannya tidaklah diukur dari seberapa tinggi pengkat dan jabatannya, nasabnya, maupun kekayaannya. Namun disisi Allah yang diukur adalah ketaqwaannya. Manusia dalam perspektif Islam akan tetap dilahirkan dalam keadaan fithrah, yaitu suci, bersih, bebas dari segala dosa, dan memiliki kecenderungan dapat menerima agama, iman, dan 
tauhid. Manusia menjadi lebih baik atau buruknya adalah akibat faktor pendidikan dan lingkungan, bukan kepada tabiat aslinya.

Berdasarkan penelitian terdahulu, beberapa penelitian telah membahas mengenai konsep manusia (Amir, 2012; Hafidz, 2008; Ismail, 2013; Lutfiyani, 2016; Pransiska, 2016; Sahadewa, 2013). serta beberapa penelitian dalam tinjauan pendidikan islam (Aslan, 2017; Faturrahman, 2016; Hidayati, 2016; Ibrahim, 1990; Ismail, 2013; Muspiroh, 2016; Najahah, 2016; Qodir, 2014; Ridlwan, 2013; Rifai, 2016; Sukring, 2016; Ulwan, 1992; Zainuddin, 2015). Namun, belum ada penelitian yang membahas mengenai konsep fitrah manusia dan implikasinya dalam pendidikan Islam. Maka, penelitian ini akan membahas mengenai bagaimana konsep fitrah manusia dan implikasinya dalam pendidikan Islam

\section{METODE PENELITIAN}

Jenis penelitian yang digunakan adalah model penelitian kualitatif dengan kajia literatur. Penelitian kualitatif bertujuan memperoleh gambaran seutuhnya mengenai suatu hal menurut pandangan manusia yang diteliti. Penelitian kualitatif berhubungan dengan ide, persepsi, pendapat, atau kepercayaan orang yang diteliti; kesemuanya tidak dapat diukur dengan angka

\section{HASIL KAJIAN DAN PEMBAHASAN}

\section{A. Hakekat Manusia}

\section{Konsep Dasar Manusia Menurut Alqur'an}

Bentuk dan peran seseorang, secara garis besar dapat dlihat dari kedudukan yang ditempatinya. Sedangkan untuk dapat mengetahui hal itu, kita perlu mengetahui penamaan yang disandangnya. Begitu pula tentang sebuah peran manusia dapat dibentuk antara lain melalui berbagai sebutan yang diberikan pada manusia.

Dalam Alqur'an manusia disebut dengan berbagai namadiantaranya: al- Basyr, al- Insan, an- Nas, dan konsep Bani Adam yang dalam hal ini sebagai penolakan terhadap teori Darwin tentang evolusi bahwa manusia adalah keturunan dari kera. Adapun pemahaman tentang peran manusia sangat erat kaitannya dengan sebutan yang disandangnya.

a. Konsep Al-Basyr ( البشر) 
Manusia dalam konsep al- Basyr, dipandang dari pendekatannya biologis. Sebagai mahluk biologis adalah manusia terdiri atas unsur materi, sehingga menampilkan sosok kedalam bentuk fisik material, yaitu berupa tubuh kasar (ragawi). (Jalaluddin, 1997)

Berdasarkan konsep Al-Basyr, manusia tidak jauh berbeda dengan makhluk biologis yang lainnya. Dengan demikian kehidupan manusia sangat terikat kepada kaidah-kaidah prinsip kehidupan biologis yang lain seperti berkembang biak, mengalami fase pertumbuhan dan perkembangan untuk mencapai tingkat kematangan serta kedewasaan. Manusia memerlukan makan, minum dengan kreteria yang halal serta bergizi. Seperti pada QS An-Nahl, ayat; 69

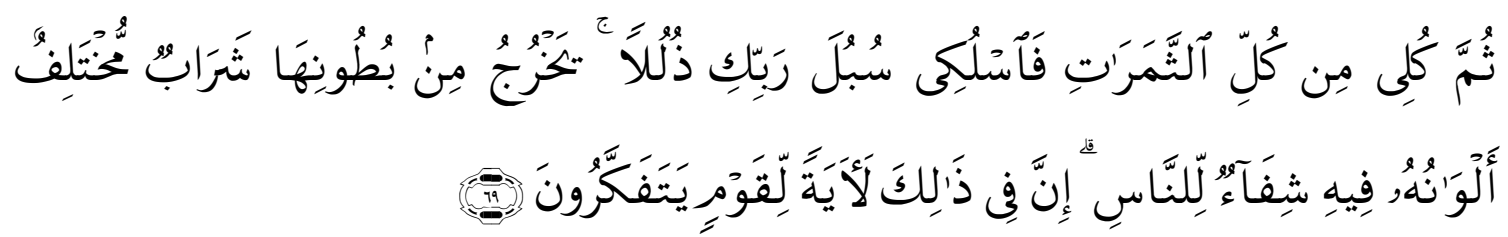

Artinya: "kemudian makanlah dari tiap-tiap (macam) buah-buahan dan tempuhlah jalan Tuhanmu yang telah dimudahkan (bagimu). dari perut lebah itu ke luar minuman (madu) yang bermacam-macam warnanya, di dalamnya terdapat obat yang menyembuhkan bagi manusia. Sesungguhnya pada yang demikian itu benar-benar terdapat tanda (kebesaran Tuhan) bagi orang-orang yang memikirkan” (Q.S An-Nahl, ayat; 69).

Ayat di atas memberikan pemahaman bahwa, Allah telah menyediakan semua bentuk makanan dan munuman bagi manusia, namun manusia diberikan Allah juga batasan akan makanan dan minuman tersebut yang halal namun tidak baik, makanan halal dan baik serta makanan yang haram .Dalam hal makanan dan minuman Allah menjelaskan dalam Al-Qur'an surat Abasa ayat 24 yang berbunyi "Hendaklah Manusia memperhatikan makanannya". Dalam al-qur'an ditemukan perintah makan sebanyak 27 kali dalam berbagai kontek dan arti, yang selalu menekankan salah satu dari dua sifat yakni halal (boleh) dan Tayyib (baik), bahkan ada empat ayat yang menggabungkan kedua perintah tersebut, yaitu; Q.S 5:88; 2:168; 8:69; dan 16:114 (Shihab, 1997) 
Selain manusia butuh akan makan dan minum yang bertujuan untuk hidup. Manusia juga butuh akan pasangan hidup melalui jalur pernikahan untuk menjaga dan melanjutkan proses keturunannya

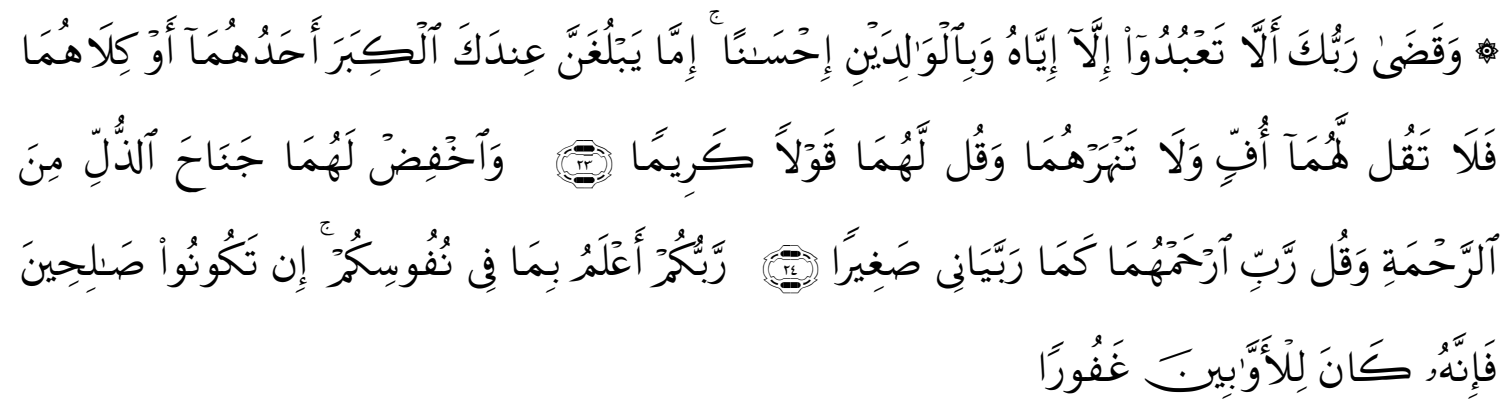

Artinya: "dan Tuhanmu telah memerintahkan supaya kamu jangan menyembah selain Dia dan hendaklah kamu berbuat baik pada ibu bapakmu dengan sebaikbaiknya. jika salah seorang di antara keduanya atau Kedua-duanya sampai berumur lanjut dalam pemeliharaanmu, Maka sekali-kali janganlah kamu mengatakan kepada keduanya Perkataan "ah" dan janganlah kamu membentak mereka dan ucapkanlah kepada mereka Perkataan yang mulia.24. dan rendahkanlah dirimu terhadap mereka berdua dengan penuh kesayangan dan ucapkanlah: "Wahai Tuhanku, kasihilah mereka keduanya, sebagaimana mereka berdua telah mendidik aku waktu kecil". 25. Tuhanmu lebih mengetahui apa yang ada dalam hatimu; jika kamu orang-orang yang baik, Maka Sesungguhnya Dia Maha Pengampun bagi orang-orang yang bertaubat.” (Q.S Al-Isra' ayat: $23-25)$.

b. Konsep Al- Insan ( الانسان )

Al-Insan terbentuk dari akar kata Nasiya (نسي), Nisyu (نسي ) yang berati lupa, dari kata Insu (نسى ) artinya senang, jinak, harmonis, dan ada juga dari akar kata Naus ) yang mengandung arti “pergerakan atau dinamisme”. Merujuk pada asal kata alInsan dapat kita pahami bahwa setiap manusia pada dasarnya memiliki potensi yang positif dalam tumbuh serta berkembang secara fisik maupun mental spiritual. Di samping itu, manusia juga diberikan dengan jumlah potensi lain, yang berpeluang untuk mendorong dirinya ke arah tindakan, sikap, serta prilaku yang negatif dan merugikan.(Jalaludin, 2001)

c. Konsep An- Nas ( الناس ) 
Kosa kata An- Nas dalam Al- Qur'an umumnya dihubungkan dengan fungsi manusia sebagai makhluk sosial. Manusia diciptakan sebagai makhluk yang bermasyarakat, yang berawal dari pasangan laki-laki dan wanita kemudian berkembang menjadi suku dan bangsa untuk saling kenal mengenal "berinterksi” Hal ini dijelaskan dalam al-qur'an surat

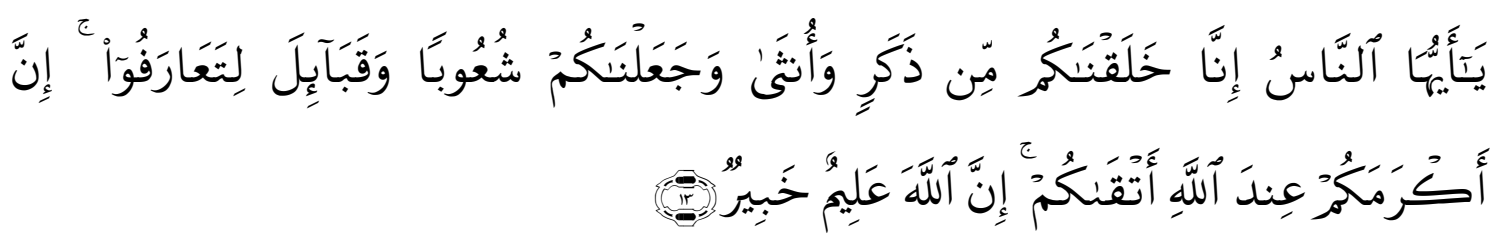

Artinya: "Hai manusia, Sesungguhnya Kami menciptakan kamu dari seorang laki-laki dan seorang perempuan dan menjadikan kamu berbangsa - bangsa dan bersuku-suku supaya kamu saling kenal-mengenal. Sesungguhnya orang yang paling mulia diantara kamu disisi Allah ialah orang yang paling taqwa diantara kamu. Sesungguhnya Allah Maha mengetahui lagi Maha Mengenal."

Hal ini sejalan dengan teori "strukturalisme" Giddens yang mengatakan bahwa manusia merupakan individu yang mempunyai karakter dan prinsip berbeda antara yang lainnya tetapi manusia juga merupakan agen social yang bisa mempengaruhi atau di bentuk oleh masyarakat dan kebudayaan di mana dirinya berada dalam konteks sosial. (Fay, 2002)

d. Konsep Bani Adam ( بنى آدم)

Manusia sebagai Bani Adam, termaktub di tujuh tempat dalam Al-Qur'an Menurut al-Gharib al-Ishfahany, Bani berarti keturunan dari darah daging yang dilahirkan.(Jalaludin, 2001) Berkaitan dengan penciptaan manusia, maka akan timbul sebuah pertanyaan apakah adam adalah manusia pertama?

Allah menggunkan kata-kata dalam al-qur'an dengan berbeda-beda dalam kontek penciptaan manusia. Seperti lafat : جعل , آنسأخلق, hal ini dapat dilihat dalam alqur'an dibawah ini:

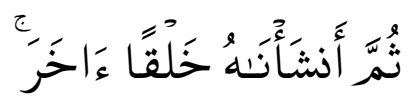

"Kemudian kami jadikan dia makhluk yang (berbentuk) lain” 


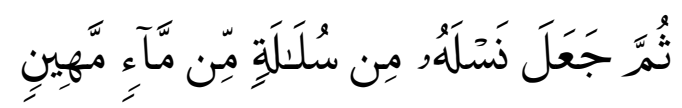

"Kemudian dia menjadikan keturunannya dari saripati air yang hina"

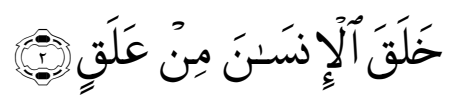

"Dia telah menciptakan manusia dari segumpal darah"

Ayat-ayat di atas mengundang manusia untuk banyak berpikir tentang proses kejadian manusia yang unik Dan banyak ayat-ayat al-Qur'an, data dan kejadian yang menunjang pemikiran ini. Seperti misalnya: Pada saat manusia akan diciptakan oleh Allah SWT untuk menjadi kalifah dibumi, bagaimana mungkin para Malaikat mengetahui bahwa manusia hanya akan membuat kerusakan diatas bumi. Sedangkan Malaikat hanya dapat mengetahui apa-apa yang diberitahukan Allah SWT kepada mereka. Tentunya karena mereka pernah mengetahui adanya "manusia" dibumi sebelum Adam AS diciptakan Allah SWT. karena itu Allah SWT selalu menyatakan bahwa: "Manusia (anak-cucu Adam AS ) diciptakan dalam kesempurnaan-nya"

\section{B. Tugas dan Fungsi Manusia}

\section{Tugas Dan Fungsi Manusia Sebagai Khalifah}

Pandangan yang menganggap manusia sebagai khalifah di bumi ini, bersumber pada firman Allah yang berbunyi:

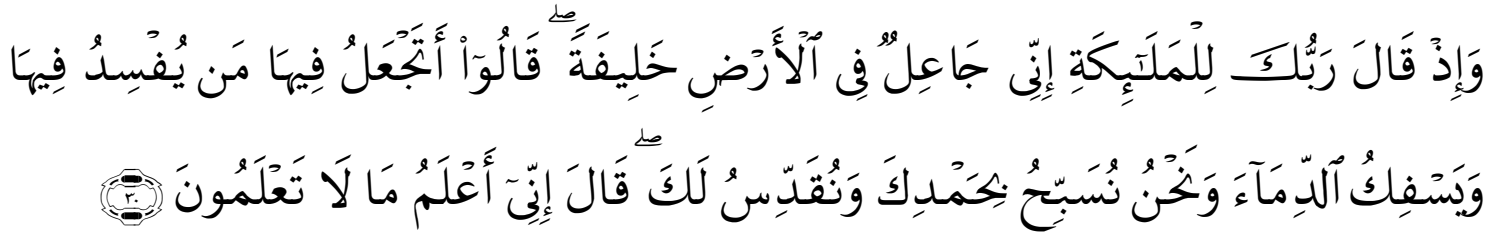

Artinya: "ingatlah ketika Tuhanmu berfirman kepada Para Malaikat: "Sesungguhnya aku hendak menjadikan seorang khalifah di muka bumi." mereka berkata: "Mengapa Engkau hendak menjadikan (khalifah) di bumi itu orang yang akan membuat kerusakan padanya dan menumpahkan darah, Padahal Kami Senantiasa bertasbih dengan memuji Engkau dan mensucikan Engkau?" Tuhan berfirman: "Sesungguhnya aku mengetahui apa yang tidak kamu ketahui." (Q.S Al-Baqarah Ayat : 30) 
Al-Qur'an tidak memandang manusia hanya sebagai makhluk yang diciptakan secara kebetulan, atau tercipta dari kumpulan atom saja, tapi ia diciptakan setelah sebelumnya direncanakan untuk menjadikan satu tugas sebagai khalifah di muka bumi ini. Manusia dibekali Allah SWT dengan potensi dan kekuatan positif untuk mengubah berbagai corak kehidupan di dunia ke arah yang lebih baik. M. Quraisy Shihab menyimpulkan bahwa kata khalifah itu mencakup dua pengertian :

a. Orang yang diberi kekuasaan untuk mengelola wilayah, baik luas maupun terbatas.

b. Khalifah memilki potensi untuk mengemban tugasnya, namun juga dapat berbuat kesalahan dan kekeliruan.

Tugas kekhalifahan tersebut memang sangat berat. Namun status ini dapat menunjukkan arah dengan peran manusia sebagai penguasa di bumi atas petunjuk Allah. Tugas manusia sebagai khalifah di bumi ini tidak semata perintah Allah untuk mengelola alam semesta ini, tanpa adanya arah dan petunjuk dari Allah, akan tetapi Allah telah membekali manusia dengan potensi-potensi, ilmu pengetahuan dan sarana untuk memahami ilmu pengetahuan.

\section{Tugas Dan Fungsi Manusia Sebagai Abdillah}

Mengabdi kepada Allah SWT (Q.S. 51:56). Sebagai hamba Allah, manusia diwajibkan untuk beribadah kepada Allah, dalam arti selalu tunduk dan patuh atas perintah-Nya guna mengesakan dan mengenal-Nya sesuai dengan petunjuk yang telah diberikannya. Ibadah mengandung dua pengertian, yaitu pengertian khusus dan pengertian umum. Dalam pengertian khusus, ibadah adalah melaksanakan peraturanperaturan yang mengatur hubungan antara hamba dan Tuhannya yang tata caranya ditur secara terperinci di dalam Al-Qur'an dan As-Sunnah, sedang ibadah dalam arti luas adalah aktivitas yang titik tolaknya ikhlas dan ditujukan untuk mencapai ridha Allah berupa amal saleh. (Ibrahim, 1990)

Dari segi sasarannya, ibadah dapat diklasifikasikan atas tiga macam, yaitu ibadah person, ibadah antarperson dan ibadah sosial.(Muhaimin, 2001)

Manusia sebagai abdillah (Mu'abbid) tidak hanya dituntut semata-mata dalam kontek ibadah wajib seperti shalat, puasa, zakat, dan lain sebagainya, tetapi juga juga bahwa segala aktivitas yang bernilai baik dalam kehidupan manusia yang dilakukan dengan tujuan pendekatan kepada sang pencipta (Allah). (Muhmidayeli, 2013) Sebagai 
Mu'abbid, manusia dalam hal ini dituntut agar mampu merefleksikan sifat-sifat Tuhan ke dalam dirinya dan menjadikan sifat-sifat Tuhan lebih aktual dalam berbagai tindakan.

Dari uraian di dapat disimpulkan, tugas manusia sebagai abdillah selain sebagai menjalankan ibadah yang diwajibkan Allah dan yang disunnahkan oleh Rosulullah saw yang bernilai baik dalam kehidupan manusia, baik berhubungan langsung dengan Allah maupun dengan sesama manusia, kewajiban dan sunnah tersebut juga harus diaktualisasikan dalam berbagai tindakan (perilaku).

\section{Pengertian Fitrah Dan Manusia}

\section{Pengertian Fitrah}

Kata "fitrah" berasal dari kata kerja (fi'il) fathara yang berarti "menjadikan". Secara etimologis fitrah berarti : kejadian, sifat semula jadi, potensi dasar, kesucian. Didalam kamus munjid ditemukan bahwa fitrah mempunyai arti yaitu sifat yang menyifati segala yang ada pada saat selesai di ciptakan. (Ramayulis, 1994)

Prof. Dr. Abdul Mujib mengutip dari imam al-qurtubi mengartikan fitrah jika dikorelasikan dengan kalimat lain, mempunyai banyak makna; (1). fitrah dapat berarti suci (al-thuhr). (2). Fitrah berarti potensi ber-islam (al-din Al-islamiy), ini bermakna bahwa fitrah berarti beragama islam. (3). Fitrah mengakui keesaan Allah (Tawhid Allah). (4). Fitrah berarti kondisi selamat(al-salamah) dan kontinuitas (istiqomah). (5). Fitrah berarti perasaan yang tulus (al-Iklas), manusia dilahirkan membawa potensi baik. (6). Fitrah berati kesanggupan menerima kebenaran. (7). Fitarh berarti potensi dasar manusia atau prasaan untuk beribadah. (Mudzakkir, 2010) Hasan Langgulung menambahkan bahwa, makna fitrah berarti; (8) Fitrah berarti ketetapan atau taqdir asal manusia mengenai kebahagian (al-sa'adat) atau kesensaraan (al-syaqawat) hidup. (9). Fitrah berarti tabiat atau watak asli manusia. (10). Fitrah berarti sifat-sifat Allah, yang ditiupkan kepada manusia sebelum lahir (Langgulung, 1995)

\section{Jenis-Jenis Fitrah}

Fitrah memiliki banyak dimensi, tetapi demensi yang terpenting adalah:

a) Fitrah Agama, Manusia sejak lahir mempunyai naluri atau insting yang beragama, dan mengakui adanya dzat Allah, namun ketika dia lahir cendrung pada al-hanif, yakni rindu akan kebenaran mutlak Allah.

b) Fitrah Intelek, Intelek adalah potensi bawaan manusia untuk memperoleh 
pengetahuan yang dapat membedakan mana yang baik dan yang buruk. Karena daya dan fitrah ini hingga dapat membedakan antara manusia dan hewan.

c) Fitrah Sosial, kecendrungan manusia untuk hidup berkelompok yang mempunyai ciri khas yang disebut kebudayaan. Oleh karena itu tugas pendidikan disini adalah menjadikan kebudayaan islam sebagai proses kurikulum pendidikan islam dalam seluruh peringkat dan tahapan.

d) Fitrah seni, Kemampuan manusia untuk menimbulkan daya estetika, yang mengacu pada sifat al-jamal Allah swt. Tugas utama pendidikan memberikan suasana gembira, senang, dan aman dalam proses belajar mengajar, karena pendidikan adalah proses kesenian, yang karenanya dibutuhkan seni mendidik.

e) Fitarh kemajuan, keadilan, kemerdekaan, kesamaan, ingin dihargai, kawin, cinta tanah air, dan kebutuhan-kebutuhan hidup lainya.

Semua kebutuhan kehidupan manusai merupakan fitrah yang menuntut untuk dipenuhi,. Sayyid Quthub mengemukakan kebutuhan pokok manusia terbagi menjadi empat macam, yaitu: (1) Kebutuhan hati nurani setiap manusia untuk memperoleh kepuasan, ketentraman, dan ketenangan. (2). Kebutuhan akal pikiran, setiap insan untuk memperoleh kebebasan, kemerdekaan, dam kepastian. (3). Kebutuhan prasaan setiap insan dapat memperoleh rasa saling pengertian, kasih sayang, dan perdamaian. (4). Kebutuhan hak dan kewajibansetiap insan untuk memperoleh perundang-undangan, ketertiban dan keadilan.

Sesungguhnya tubuh manusia terdiri dari dua jenis, yaitu: Tubuh kasar dan tubuh halus, atau jasmani/fisik dan ruhani/ruh. Manusia tanpa jasmani belum bisa dikatakan manusia, demikian dengan manusia tanpa ruh tidak dapat dikatakan manusia hidup.Jasmani manusia berasal dari materi tanah, sedangkan ruh manusia berasal dari Allah yaitu Tuhan semesta alam(Unila, 2014)

\section{Konsep Tentang Fithrah}

Rasulullah SAW bersabda : "Anak-anak lahir dalam keadaan fithrah, orangtuanyalah yang menjadikannya Yahudi, Majusi, atau Nasrani.” (HR. Bukhari) Menurut Yasien Muhammad, pemahaman terhadap konsep fithrah ini ada empat, yaitu pandangan fatalis, pandangan netral, pandangan positif, dan pandangan dualis.

a). Pandangan Fatalis 
Dalam pandangan fatalis ini mempercayai bahwa setiap individu, melalui ketetapan Allah, adalah baik atau jahat secara asal, baik ketetapan semacam ini terjadi secara semuanya atau sebagian sesuai dengan rencana Tuhan. Syaikh Abdul Qadir Jailani mengungkapkan bahwa seorang pendosa akan masuk surga jika hal itu menjadi nasibnya yang telah ditentukan Allah sebelumnya. Dengan demikian, tanpa memandang faktor-faktor eksternal dari petunjuk dan kesalahan petunjuk, seorang individu terikat oleh kehendak Allah untuk menjalani 'cetak biru' kehidupannya yang telah ditetapkan baginya sebelumnya.

b). Pandangan Netral

Pandangan netral ini dikomandani oleh Ibnu 'Abd al-Barr dengan mendasarkan pada firman Allah :

"Dan Allah mengeluarkan kamu dari perut ibumu dalam keadaan tidak mengetahui sesuatu pun” (QS. an-Nahl ayat: 78)

Penganut pandangan netral berpendapat bahwa anak terlahir dalam keadaan suci, suatu keadaan kosong sebagaimana adanya, tanpa kesadaran akan iman atau kufur. Menurut pandangan netral, iman atau kufur hanya mewujud ketika anak tersebut mencapai kedewasaan (taklif). Setelah mencapai taklif, seseorang menjadi bertanggung jawab atas perbuatannya.

c). Pandangan Positif

Penganut pandangan positif ini adalah Ibnu Taimiyah, Ibnu Qoyyim al-Jauziyah (salaf), Muhammad Ali Ash-Shabuni, Mufti Muhammad Syafi'i, Ismail Raji al-Faruqi, Mohamad Asad, Syah Waliyullah (kontemporer).

Menurut Ibnu Taimiyah, semua anak terlahir dalam keadaan fithrah, yaitu dalam keadaan kebajikan bawaan, dan lingkungan sosial itulah yang menyebabkan individu menyimpang dari keadaan ini. Muhammad 'Ali Ash-Shabuni mengatakan bahwa kebaikan menyatu pada manusia, sementara kejahatan bersifat aksidental. Manusia secara alamiah cenderung kepada kebaikan dan kesucian. Akan tetapi, lingkunganlingkungan sosial, terutama orangtua, bisa memiliki pengaruh merusak terhadap fithrah anak.

Ibnu Taimiyah berpendapat bahwa terdapat suatu kesesuaian alamiah antara fithrah dan dien Islam. Agama Islam menyediakan kondisi ideal untuk mempertahankan 
dan menyediakan kondisi ideal untuk mempertahankan dan mengembangkan sifat-sifat bawaan manusia.

d). Pandangan Dualis

Tokoh utama pandangan dualis adalah Sayyid Quthb dan 'Ali Shari'ati. Pandangan suatu sifat dasar yang bersifat ganda. Menurut Sayyid Quthb, dua unsur pembentuk esensial dari struktur manusia secara menyeluruh, yaitu ruh dan tanah, mengakibatkan kebaikan dan kejahatan sebagai suatu kecenderungan yang setara pada manusia, yaitu kecenderungan untuk tersesat. Kebaikan yang ada dalam diri manusia dilengkapi dengan pengaruh-pengaruh eksternal seperti kenabian dan wahyu Tuhan sementara kejahatan yang ada dalam diri manusia dilengkapi faktor eksternal seperti godaan dan kesesatan.

Shari'ati berpandangan bahwa tanah-simbol terendah dari kehinaan digabungkan dengan Ruh (dari) Allah. Dengan demikian, manusia adalah makhluk berdimensi ganda dengan sifat dasar ganda, suatu susunan dari dua kekuatan, bukan saja berbeda, tapi juga berlawanan. Yang satu cenderung turun kepada materi dan yang lain cenderung naik kepada Ruh Suci (ciptaan) Allah.

\section{Fitrah Manusia dan Implikasinya Terhadap Pendidikan Islam.}

Menurut Hasan Langgulung, fitrah adalah potensi yang baik. Haditsh yang bermakna "Setiap anak-anak dilahirkan dengan fitrah. Hanya ibu bapaknyalah yang menyebabkan ia menjadi Yahudi, Nasrani, atau Majusi”. Tetapi hal ini tidak bermakna bahwa manusia itu menjadi hamba kepada lingkungan, seperti pendapat ahli-ahli behaviorisme. Fitrah adalah sifat-sifat Tuhan yang ditiupkan Tuhan kepada semua manusia sebelum lahir, dan pengembangan sifat-sifat itu setinggi-tingginya. Senada dengan hal ini, menurut Dr. Jalaluddin, manusia memiliki beberapa potensi utama yang secara fitrah dianugerahkan Allah kepadanya, yaitu :

a). Hidayat al-Ghariziyat (potensi naluriah)

Hidayat al-Ghariziyat (potensi naluriah) Yaitu dorongan primer yang berfungsi untuk memelihara keutuhan dan kelanjutan setiap manusia. Diantara dorongan tersebut berupa instink untuk memelihara diri, seperti makan, minum, penyesuaian tubuh terhadap lingkungan dan sebagainya.

b). Hidayatu al-Hassiyat (potensi inderawi) 
Hidayatu al-Hassiyat (potensi inderawi) Potensi inderawi erat kaitannya dengan peluang manusia untuk saling mengenal sesuatu diluar dari dirinya. Melaui alat indera penglihatan, penciuman, pendengaran, perasa, peraba dan lain-lain c). Hidayat al-Aqliyyat (potensi akal)

Potensi akal memberi kemampuan pada manusia untuk memahami simbol-simbol, hal-hal yang abstrak, menganalisa, membandingkan maupun membuat kesimpulan dan dapat memilih hal yang benar atau salah. Akal juga dapat mendorong manusia berkreasi dan berinovasi dalam menciptakan kebudayaan serta peradaban.

d). Hidayat al-Diniyyat (potensi keagamaan)

Pada diri manusia sudah ada dorongan keagamaan yaitu dorongan untuk mengabdi kepada sesuatu yang lebih tinggi, yaitu Tuhan yang menciptakan alam semesta beserta isinya.(Jalaludin, 2001)

Implikasi lainnya adalah pendidikan Islam diarahkan untuk bertumpu pada tauhid. Hal ini dimaksudkan untuk menciptakan hubungan yang mengikat manusia dengan Allah Swt. Apasaja yang dipelajari anak didik seharusnya tidak bertentangan dengan prinsip-prinsip tauhid. Untuk itu kurikulum pendidikan Islam harus menekankan pada konsep tauhid ini.(Mujib, 1993)

Bagaimana cara mengembangkan potensi-potensi (fitrah) ini dalam pendidikan Islam, menurut Dr. Jalaluddin dapat dilakukan dengan berbagai cara dan pendekatan yaitu :

1). Pendekatan Filosofis

Pendekatan ini mengacu pada hakikat penciptaan manusia itu sendiri yaitu sebagai makhluk ciptaan Allah (Q.S. 51:56). Dalam filsafat pendidikan Islam nilai-nilai ilahiyat merupakan nilai-nilai yang mengandung kebenaran hakiki. Berasarkan hal ini, pengembangan potensi manusia diarahkan untuk memenuhi jawaban yang mengacu pada permasalahan yang menyangkut pengabdian kepada Allah. Sedangkan ungkapan rasa syukur digambarkan dalam bentuk penghayatan terhadap nilai-nilai akhlak yang terkandung didalamnya serta mampu diimplementasikan dalam sikap dan prilaku, lahiriah maupun batiniah. Kesadaran seperti ini timbul atas dorongan dari dalam bukan atas pengaruh luar.

2). Pendekatan kronologi 
Pendekatan kronologis yaitu pendekatan yang didasarkan atas proses perkembangan melalui tahapan-tahapan. Manusia dipandang sebagai makhluk yang evolutif. Disadari bahwa manusia bukan makhluk siap jadi, yakni setelah lahir langsung menjadi dewasa. Manusia adalah makhluk yang berkembang secara evolusi. Namun bukan dalam arti evolusi dari teori Darwin yang mengidentifikasikan manusia berasal dari genus yang sama dengan simpanse. Dalam hal ini adalah manusia sejak lahir menginjak dewasa, perkembangan manusia melalui periodisasi.

3). Pendekatan fungsional

Setiap potensi yang dianugerahkan Allah kepada manusia tentunya diarahkan untuk dimanfaatkan. Tuhan sebagai Pencipta, mustahil menciptakan sesuatu tanpa tujuan, hingga terkesan mengadakan sesuatu yang sia-sia. Semua yang diciptakannya mempunyai tujuan, termasuk yang berkaitan dengan penciptaan potensi manusia. Melalui pendekatan fungsional, dimaksudkan bahwa pengembangan potensi manusia dilihat dalam kaitannya dengan fungsi-fungsi potensi itu masing-masing. Dorongan naluriah, seperti makan dan minum dikembangkan dengan tujuan agar manusia dapat memlihara kelanjutan hidup manusia. Dengan menggunakan pendekatan ini diharapkan agar arah perkembangan potensi yang ada pada manusia tidak menjadi sia-sia. Dan kaitannya dengan fungsi manusia sebagai mengabdi (menyembah) Allah dengan setia dan ikhlas.

\section{4). Pendekatan sosial}

Manusia pada konsep al-Nas lebih ditekankan pada statusnya sebagai makhluk sosial. Berdasarkan pendekatan ini, manusia dilihat sebagai makhluk yang memiliki dorongan untuk hidup berkelompok dan bermasyarakat. Melalui pendekatan sosial, peserta didik dibina dan dibimbing sehingga potensi yang dimilikinya, yaitu sebagai makhluk sosial, dapat tersalur dan sekaligus terarah pada nilai-nilai yang positif.

\section{E. Pengembangan Fithrah Manusia}

Manusia diciptakan Allah selain menjadi hamba-Nya, juga menjadi khalifah di muka bumi. Selaku hamba dan khalifah, manusia telah diberi kelengkapan kemampuan jasmaniah (fisiologis) dan rohaniah (mental psikologis) yang dapat dikembangtumbuhkan seoptimal mungkun, sehingga menjadi alat yang berdaya guna dalam ikhtiar kemanusiaannya untuk melaksanakan tugas pokok kehidupannya di dunia. Pendidikan 
merupakan sarana yang menentukan sampai di mana titik optimal kemampuankemampuan tersebut dapat dicapai .(Arifin, 1994)

1). Menyalurkan Bakat Fithri Anak

Di antara masalah terpenting yang harus diperhatikan ialah mengetahui bakat dan pekerjaan yang sesuai dengan anak, yang menjadi cita-cita hidupnya. Diantara anakanak terdapat kesenjangan dalam hal kecerdasan dan kemampuan. Seorang pendidik yang bijaksana atau seorang ayah yang jeli akan mampu menempatkan anak di tempat yang sesuai dengan bakat dan kecenderungannya di lingkungan yang kondusif. Bagi seorang pendidik, terutama orang tua, hendaknya ia tidak menghambat bakat yang kelak menjadi harapan anak dalam hidup. Jika seorang anak berambisi meraih ilmu karena memang ia cerdas, maka orang tua tidak boleh menghalanginya.(Ulwan, 1992)

2). Proses Internalisasi Nilai-Nilai Islami

Pendidikan sebagai proses menginternalisasikan nilai-nilai dalam pribadi anak didik, bertumpu pada kemampuan atau kapasitas belajar dalam tiap pribadi anak. Proses internalisasi nilai ini dapat dilakukan melalui 2 macam pendidikan yaitu pendidikan yang dilakukan oleh dirinya sendiri dan pendidikan melalui orang lain. Peranan pendidikan diri sendiri yang dipadukan dengan pendidikan melalui orang lain, adalah lebih memperkokoh terwujudnya kebulatan dan keutuhan pola kepribadian.

Pengembangan kemampuan manusia melalui pendidikan tidaklah menjamin akan terbentuknya watak dan bakat yang baik menurut kehendak yang menciptakan, karena Allah sendiri telah menggariskan bahwa di dalam diri manusia terdapat dua kecenderungan yaitu arah fasiq dan arah ketaqwaan. Manusia diberi kemungkinan untuk mendidik diri orang lain menjadi sosok pribadi yang beruntung sesuai kehendak Allah melalui berbagai metode ikhtiariyahnya.

\section{F. Tugas Pendidikan Dalam Menjaga Fitrah Manusia}

Menurut Abd al-Rahman al-Bani yang dikutip an-Nahlawi menyatakan ugas pendidikan islam menjaga dan memelihara fitrah peserta didik, mengembangkan dan mempersiapkan segala potensi yang dimiliki, dan mengarahkan futrah dan potensi tersebut menuju kebaikan dan kesempurnaan, serta merealisasikan program tersebut secara bertahap.(Nahlawi, 1996) Pengembangan fitrah manusia dapat dilakukan dengan kegiatan belajar. Yaitu melalui berbagai institusi. Belajar yang dimaksud tidak terfokus 
melalui pebdidikan disekolah saja, tetapi juga dapat dilakukan diluar sekolah, baik dalam keluarga, masyarakat, maupun lewat isnstitusi sosial keagamaan yang ada.

\section{SIMPULAN DAN SARAN}

Manusia dalam perspektif Islam akan tetap dilahirkan dalam keadaan fithrah, yaitu suci, bersih, bebas dari segala dosa, dan memiliki kecenderungan sikap menerima agama, iman, dan tauhid. Manusia menjadi baik atau buruknya adalah akibat faktor pendidikan dan lingkungan, bukan kepada tabiat aslinya. Menurut Abd al-Rahman alBani yang dikutip an-Nahlawi menyatakan tugas pendidikan islam adalah menjaga dan memelihara fitrah peserta didik, kemudian mengembangkan dan mempersiapkan ssemua potensi yang dimiliki, dengan mengarahkan fitrah dan potensi yang ada dan menuju kebaikan dan kesempurnaan, serta merealisasikan suatu program tersebut secara lebih bertahap.

Pengembangan fitrah manusia dapat dilakukan dengan berbagai kegiatan belajar. Yaitu melalui sebuah institusi. Pengembangan fitrah manusia dapat dilakukan dengan kegiatan belajar. Yaitu melalui berbagai institusi. Belajar yang dimaksud dengan tidak terfokus yakni melalui pendidikan disekolah saja, tetapi juga dapat dilakukan diluar sekolah, baik dalam keluarga, masyarakat, maupun lewat isnstitusi sosial keagamaan yang ada. 


\section{DAFTAR PUSTAKA}

Amir, D. (2012). Konsep Manusia dalam Sistem Pendidikan Islam. Al-Ta'lim2, 1(3), $188-200$.

Arifin, H. M. (1994). Filsafat Pendidikan Islam. Jakarta: Bumi Aksara.

Aslan. (2017). Pendidikan Remaja Dalam Keluarga di Desa Merabuan, Kalimantan Barat ( Perspektif pendidikan Islam). Al-Banjari, 16(1), 122-135.

Faturrahman, M. (2016). Pendidikan Karakter Dalam Perspektif Pendidikan Islam. Edukasi, 4(1), 1-25.

Fay, B. (2002). Filsafat Ilmu Sosial Kontemporer. Yogyakarta: Jendela.

Hafidz. (2008). Konsep manusia yang menyejarah sebagai dasar pengembangan epistemologi pendidikan Islam. Jurnal Filsafat, 18(2), 1-19.

Hidayati. (2016). Pendidikan Anti Korupsi Tinjauan Perspektif Pendidikan Islam. Hikmah: Jurnal Pendidikan Islam, 5(1), 100-128.

Ibrahim, M. (1990). Pendidikan Agama Islam Untuk Mahasiswa. Yogyakarta: Erlangga.

Ismail, S. (2013). Tinjauan Filosofis Pengembangan Fitrah Manusia dalam Pendidikan Islam. At-Ta'dib, 8(2), 242-263.

Jalaluddin. (1997). Psikologi Agama. Jakarta: Raja Grafindo Persada.

Jalaludin. (2001). Teologi Pendidikan. Jakarta: Rajawali Press.

Langgulung, H. (1995). Pendidikan Islam dan Peralihan Paradigma. Selangor: Hizbi.

Lutfiyani. (2016). Pendidikan Karakter Dibentuk Dari Fitrah Manusia. Hikmah: Jurnal Pendidikan Islam, 5(1), 129-145.

Mudzakkir, A. . (2010). Ilmu Pendidikan Islam. Jakarta: Prenada Media.

Muhaimin. (2001). Paradigma Pendidkan Islam. Bandung: Rosda Karya.

Muhmidayeli. (2013). Filsafat Pendidikan. Bandung: Refika Aditama.

Mujib. (1993). Pemikiran Pendidikan Islam (kajian Filosofik dan kerangka Operasionalnya). Bandung: Trigenda.

Muspiroh, N. (2016). Integrasi Nilai Islam Dalam Pembelajaran IPA ( Perspektif Pendidikan Islam). Jurnal Pendidikan Islam, 28(3), 484-498.

Nahlawi, A. (1996). Pendidikan Islam di Rumah Sekolah dan Masyarakat. Jakarta: Gema Insani Press.

Najahah. (2016). Pemberdayaan Masyarakat Dalam Perspektif Pendidikan Islam. Jurnal Lentera Pendidikan LPPM UM Metro, 14(2), 135-147.

Pransiska, T. (2016). Konsepsi Fitrah Manusia Dalam Perspektif Islam Dan Implikasinya Dalam Pendidikan Islam Kontemporer. Jurnal Ilmiah DIDAKTIKA, 17(1), 1-17. 
Qodir, Z. (2014). Deradikalisasi Islam dalam Perspektif Pendidikan Agama. Jurnal Pendidikan Islam, 2(1), 85-107.

Ramayulis. (1994). Ilmu Pendidikan Islam. Jakarta: PT Raja Grafinda Persada.

Ridlwan, N. A. (2013). Konsep Pendidikan Karakter Dalam Perspektif Islam. Komunika, 7(1), 1-11.

Rifai, M. (2016). Peranan Orang Tua Sebagai Wali, Pembimbing, dan Pendidik Pada Perkembangan Anak Dalam Perspektif Pendidikan Agama Islam. Premiere Educandum, 1(1), 1-10.

S, N. (2001). Pengantar Dasar-Dasar Pemikran Pendidikan Islam. Jakarta: Media Pratama.

Sahadewa, N. W. (2013). Konsep Manusia Menurut Mohandas Karamchand Gandhi. Jurnal Filsafat, 23(1), 1-20.

Shihab, M. . (1997). Membumikan Al-Quran. Bandung: Mizan.

Sukring. (2016). Pendidik dalam Pengembangan Kecerdasan Peserta didik ( Analisis Perspektif Pendidikan Islam). Tadris, 1(1), 57-68.

Ulwan. (1992). Pendidikan Anak Menurut Islam Kaidah-kaidah Dasar. Bandung: Remaja Rosdakarya.

Unila, T. . (2014). Pendidikan Agama Islam Berbasis Karakter di Perguruan Tinggi. Jakarta: PT Raja Grafinda Persad.

Zainuddin, M. R. (2015). Peran Pondok Pesantren Dalam Perspektif Pendidikan Islam. Edukasi, 3(1), 751-764. 